\title{
Value Creation in Microfinance Institutions for Creating Holistic Accountability
}

\author{
Siti Amerieska*, Imam Mulyono, Novi Nugrahani \\ Department of Accounting \\ Polytechnic State of Malang \\ Malang, Indonesia \\ *siti.amerieska@polinema.ac.id
}

\begin{abstract}
The study aims for three main objectives: (1) Creating value creation accountability with value driven accounting principles, (2) Definition of the principle of value creation in each accountability, were are economic accountability, social accountability, environmental accountability and spiritual accountability, (3) Arrange a holistic accountability model, which has orientation strategy to preserve sustainability. This study used qualitative research methods. The selection of qualitative methods is to provide a new perspective on accountability. The results of this study indicate that in BMT there are still human-centered accountability superiortas, this is seen from the level of accountability which the first level is aimed at the board of supervisors, the second level, management accountability is directed at the Annual Member Meeting, whereas at the third level, management accountability is in the form of accountability to God, then the programs carried out in BMT activities still prioritize programs that are of economic and social needs (accountability economic and social accountability), while accountability to nature is still carried out indirectly with the existence programs.
\end{abstract}

Keywords: value creation, values driven shariah accounting, BMT, holistic accountability

\section{INTRODUCTION}

Business management requires the ability to always adapt to a changing environment's demands [1]. Strategic environmental conditions are those that want and attempt to adapt to the problems of the times (global competition, management and accountability openness / transparency). Forms of concern for the surrounding environment and became accountable are one form that has a significant influence on a company $[2,3]$.

Accountability is one of the foundations for the creation of trust in the things entrusted. Without accountability it is not impossible that trust in a community will cease. Responding to the importance of accountability [4,5], this research will explain what accountability is, how accountability relates to accounting, basically these two things are interrelated. From an economic point of view, accounting is seen as a medium of accountability, which is an activity related to the effort to produce information in the framework of accountability (accountability). Accounting as an instrument of responsibility has a function as a tool for controlling the activities of the company.
This study is motivated by several different aspects: (1) Accountability in microfinance is currently experiencing a paradigm was going to change. Where originally accountability was packaged as a reporting obligation based on the dimensions of the value of transparency, liability, control, (2) accountability information is meaningless if there is no balance of profit information, people, planet, (3) Changes in the business environment, especially in the financial sector, necessitates the company's strategy to be able to sustainable and intense competition.

To elaborate these three motivations, the study aims for three main objectives: (1) Creating value creation accountability with value driven accounting principles, (2) Definition of the principle of value creation in each accountability, were are economic accountability, social accountability, environmental accountability and spiritual accountability, (3) Arrange a holistic accountability model, which has orientation strategy to preserve sustainability.

Religious business and social organizations that fall into the micro finance category, namely BMT (Baitul Maal Wat Tamwil). The results of this study indicate that in BMT there are still superiortas of accountability that are centered on humans, this is seen from the level of accountability where the first level is aimed at the supervisory board. The second level, management accountability is directed at the Annual Member Meeting. While at level three, management accountability is in the form of accountability to God. Then the programs carried out in BMT activities still prioritize programs that are of economic and social needs (economic accountability and social accountability). While accountability to nature is still carried out indirectly with the existence of agricultural extension programs that provide awareness for nature conservation efforts with greening.

\section{LITERATURE REVIEW}

\section{A. Business Model BMT}

In line with the changing times, changes in economic order and trade, the concept of Baitul Mall has also changed, not limited to receiving and distributing assets but also managing them more productively to empower the community's economy. In Indonesia, the term baitul maal wat tamwil began to develop since 1992. Initially this institution was merely collecting and distributing ZIS (zakat, infaq, sadaqah) from employees or employees of an agency to be distributed to the 
mustahiknya, then developed into an economic institution shaped all-round cooperatives engaged in savings and loans and businesses in the real sector. Baitul Maal Wat Tamwil (BMT) which was established based on Islamic values, certainly has different characteristics compared to cooperatives in general. BMT is a Syariah cooperative that has been proven to empower middle and lower class people. In the decade (1995-2005) it has grown and developed more than 3,300 BMTs in Indonesia. The experience shows that BMT provides hope to the community in the aspects of sharia, besides that it can also provide broad benefits in the economic and social empowerment. BMT's ability to empower people is a potential that needs to be fostered, as well as be proud of.

\section{B. Relationship Between Accountability and Stewardship Theory}

The concepts of stewardship offer an alternative to the philosophy of principal agents to improve contract arrangements and to maintain responsibility within them. Stewardship theory may imply that an internal sense of responsibility is generated when a principal and an agent share the same core values - when their values converge and accountable actions can result [6]. The theories of stewardship differ from the theories of principal agents in the following two important respects: (a) the key interest driving actions under stewardship theories is public service, and (b) stewardship theories accept the likelihood of motivational altruism.3 It is on these two distinct grounds that accountability approaches derived from stewardship theory are most likely to vary from outside.

\section{Accountability in the View of Values Driven Shariah Accounting (VDSA)}

Values Driven Shariah Accounting (VDSA) has a balance character that balances egoistic values with altruistic values and material values with spiritual values. The consequence of this balance value causes VDSA not only to care about individual interests, but also other parties. For this reason, VDSA's view of accountability states that there are three dimensions of accountability relationships. The first dimension of the relationship is to God as the creator and sole owner of all resources. Existing in this world. So, what applies in Values Driven Shariah Accounting (VDSA) is God as the main source, because $\mathrm{He}$ is the sole and absolute owner. The resources owned by the stakeholders are basically mandate from God which is inherent in a responsibility to use in the manner and purpose set by the Giver of Trust. So that the purpose of using this resource is nothing but getting mardhatillah. How can this goal be achieved only if the servant uses it in a way that can turn this resource into rahmatan lil alamin.

The second dimension of accountability is human to human, divided into two groups, namely direct stakeholders and indirect stakeholders. Direct stakeholders are parties who directly contribute to the company both in the form of financial and non-financial contributions. While indirect stakeholders are parties that do not contribute to the company either financially or non-financially, but in sharia they are parties who entitled to get welfare from the company.

While the last stakeholder group or the accountability relationship dimension of VDSA is nature. Nature is a vital ecosystem that contributes to the survival of the company. Balance in preserving nature is the main point in creating harmony in harmony and balance. The company will still exist if it pays attention to its natural environment. Various cases of waste pollution carried out, will indirectly damage the ecosystem and also people's trust in the company. To make it easier to describe the form of accountability possessed by VDSA, the figure below will illustrate how the model of accountability relations in various dimensions of accountability relationships.

\section{METHODS}

This study used qualitative research methods. The selection of qualitative methods is to provide a new perspective on accountability as a whole (holistic), with assumption that the understanding of accountability is not enough just mathematically in the form of numbers (physical) which are described in the financial statements but rather understood in the form of individual behavior in implementing accountability. With qualitative methods the researcher also intends to see firsthand the phenomenon and reality of BMT accountability more deeply seen in a more holistic aspect.

In this study, researchers obtained main data by making direct observations to the research object, interviewing management and stakeholders, and interacting directly with the management of the research object. Observations were made directly at the location of the object of research with the aim of getting a picture of the reality of the actions taken by each individual and reinforced by interviewing the object. This observation lasted for a relatively long period of three (3) months, starting at the time the researcher first observed general office conditions. Based on the scheme of accountability model development is carried out with six stages:

1) Identification of problems,

2) Formulation of development models,

3) Preparation of models and development of syntax prototypes, model scenarios,

4) Trials of syntax prototypes and model scenarios,

5) Evaluate the feasibility of the prototype syntax,

6) Refinement and communication of results. The development of the accountability model design is carried out by an iteration process between researchers, as well as stakeholders.

\section{RESULTS AND DISCUSSION}

The results of this study indicate that in BMT there are still human-centered accountability superiortas, this is seen from the level of accountability which the first level is aimed at the board of supervisors, the second level, management accountability is directed at the Annual Member Meeting, whereas at the third level, management accountability is in the form of accountability to God, then the programs carried out in BMT activities still prioritize programs that are of economic and social needs (accountability economic and social accountability), while accountability to nature is still carried out indirectly with the existence of agricultural extension programs that provide awareness for businesses. 
VDSA is described in fourth main aspects namely Value Creation of Stakeholders, Focus on performance, Holistic Accountability. The following explanation of the fourth aspects:

\section{A. Value Creation in Economic Accountability.}

This accountability emphasizes business processes oriented to value creation to maximize customer value, reengineering the business for continuous improvement. BMT is an institution that acts as a financial intermediary (financial intermediary) between parties who have funds and those who need funds. BMT members are a group of people who are registered as members, who annually receive SHU from BMT operations, while customers are not necessarily members. In addition to being entitled to receive SHU, members can also enjoy all BMT products offered (deposits and financing). BMT customers can be divided into two, namely depositors (savings and deposit customers) and credit customers. The implications of the existence of BMT to its depositors can be seen from the amount of savings and time deposit payments. Growth in the amount of savings receipts and time deposits is an economic indicator that can be used to see the level of confidence of depositors in managing funds carried out by BMT. Daily profit-sharing ratio is 30:70, (30 customers, $70 \mathrm{BMT}$ ).

\section{B. Value Creation in Social Accountability.}

This accountability emphasizes on two aspects, namely internal aspects (employment, environment, work atmosphere), while external aspects are in the form of empowering local people, indigenous peoples, settlements, cultural heritage [7]. Social accountability here emphasizes aspects of community empowerment. Where the role of the community and the company can be created properly. Programs that can be carried out are divided into two, namely internal and external aspects of social accountability [6]. For the aspect of internal accountability can be done in a way to empower employees, build a mindset of the importance of building a business with awareness of providing the best service, by providing the best service customer satisfaction will be created so that loyalty and trust in using financial services is increasing. The external dimension of social responsibility allows the surrounding community to be motivated by their participation in the success of building companies. For the economy, the idea used is to provide credit loans to the community with an emphasis on heritage business because it is to protect cultural heritage. Loan services that take advantage of the concept of social harmony and solidarity must be promoted

\section{Value Creation in Ecologycal Accountability}

The emphasis on environmental accountability lies in how a company creates value supports environmental sustainability. Such as: (1) Ihya al-mawat, reviving abandoned land by reclamation or functioning of the area to be productive. (2) Iqta, land permitted by the state for agricultural purposes as cultivated land for developers or investors. (3) Ijarah, land rent for agriculture. (4) Harim, protected area. (5) Hima, a protected area for public benefit and preservation of natural habitats.

The dimension of human relations with the natural environment (ecological accountability) can be related to BMT activities by looking at BMT's involvement in activities aimed at the welfare of the universe.

\section{Value Creation in Spiritual Accountability}

Concerned with the interests of direct and indirect stakeholders and nature. Management's belief in employees that the company they work for is a mandate from Allah to be managed together. Of course, all of this begins with a good role model of leadership with leadership that is filled with an atmosphere of honesty and justice Allah SWT will provide blessings and blessing.

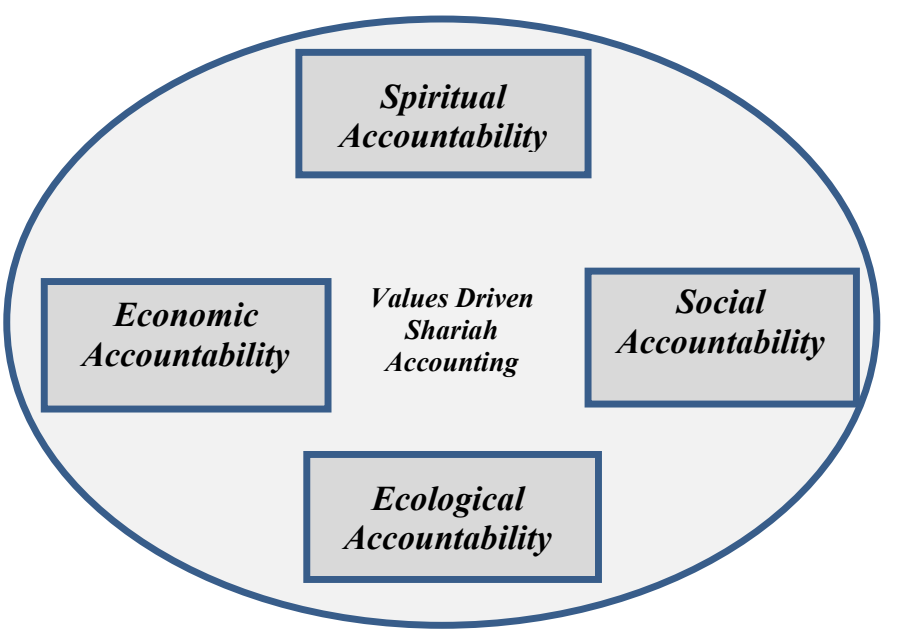

Fig. 1. Holistic accountability based on values driven shariah accounting.

\section{E. Values Driven Shariah Accounting}

Values Driven Shariah Accounting is the formation of value creation for all stakeholders. Which is the Islamic values adopted in carrying out business processes. Accounting in this model is also used in the art of recording and reporting businesses 'control of financial, social and natural Resources.

\section{F. Values Driven Shariah Accounting in Economic Accountability.}

Prepare financial statements oriented to creating value to all stakeholders. Such as calculating customer profitability analysis but also seeing the qualitative aspects of how to provide good service in order to increase customer value

\section{G. Values Driven Shariah Accounting in Social Accountability.}

Social value must be generated in the entity's annual report describing the management of economic resources on the basis of community empowerment and also the creation of the entity's internal and external environmental values

\section{H. Values Driven Shariah Accounting in Ecological Accountability}

Green branding of the financial products produced, such as the development of green financial products.

This means that in addition to providing credit customer also led to contribute to environmental improvement 
compared with other research sites that have similar conditions. The second limitation is the limitation of the process, and the third is the limited ability of researchers to analyze and reveal various phenomena encountered at the research site. Researchers are often faced with different interpretations of phenomena and informants' opinions on various issues that make it difficult for researchers to conduct analyzes and make conclusions.

\section{REFERENCES}

This study was conducted in the context of religious business and social organizations included in the micro finance category, namely BMT (Baitul Maal Wat Tamwil. The results of this study indicate that in BMT there are still humancentered accountability superiortas, this is seen from the level of accountability which the first level is aimed at the board of supervisors, the second level, management accountability is directed at the Annual Member Meeting, whereas at the third level, management accountability is in the form of accountability to God, then the programs carried out in BMT activities still prioritize programs that are of economic and social needs (accountability economic and social accountability), while accountability to nature is still carried out indirectly with the existence of agricultural extension programs that provide awareness for conservation efforts with greening.

Some things that become limitation in this research are: first, this research is classified as a case study because it is only done on one BMT. Perceptions, attitudes, and behaviors found at this research site may be different from other sites so that the results of this study cannot be generalized but can only be
[1] C. Humphrey and P. Miller, "Rethinking impact and redefining responsibility: The parameters and coordinates of accounting and public management reforms". Accounting, Auditing and Accountability Journal, 25(2), 295-327. 2012.

[2] M. Frostenson and S. Helin, "Ideas in conflict: a case study on tensions in the process of preparing sustainability reports". Sustainability Accounting, Management and Policy Journal, 8(2), 166-190. 2017.

[3] P. Ratajczak and D. Szutowski, "Exploring the relationship between CSR and innovation". Sustainability Accounting, Management and Policy Journal, 7(2), 295-318. 2016.

[4] K. Jacobs, "Theorising Interdisciplinary Public Sector Accounting Research". Financial Accountability and Management, 32(4), 469-488. 2016.

[5] S. Du Rietz, "Information vs knowledge: Corporate accountability in environmental, social, and governance issues". Accounting, Auditing and Accountability Journal, 31(2), 586-607. 2018.

[6] E. Costa and C. Pesci, "Social impact measurement: why do stakeholders matter?" Sustainability Accounting, Management and Policy Journal, 7(1), 99-124. 2016.

[7] A. Kamaluddin, N. Kassim, M.M. Alam, and S.A.A. Samah, "Human capital accountability and construct: Evidence from Islamic microfinance institutions in Malaysia". Global Journal Al-Thaqafah, 2018 (January), 117-130. 2018. 